\title{
Effect of Foliar spray with Potassium Silicate on Growth, Yield, Quality and Storability of Cucumber Fruits
}

\author{
Shehata, S.A. ${ }^{1}$; Saad, M.EL-M. ${ }^{2}$;Saleh,M.A. ${ }^{2}$ and Atala, S.A. ${ }^{2}$ \\ ${ }^{1}$ Vegetable Crops Department, Faculty of Agriculture, Cairo University, Giza, Egypt. \\ ${ }^{2}$ Postharvest and Handling of Vegetable Crops Research Department, Horticulture Research Institute, \\ Agricultural Research Center, Giza, Egypt. \\ Correspondence author: Said_Shehata2@yahoo.com
}

\begin{abstract}
The experiment was carried out under plastic house conditions during autumn seasons of 2016 and 2017 at the Agricultural Experiment Station, Faculty of Agriculture, Cairo University and Laboratory of Handling of Vegetable Department, Horticulture Research Institute, Giza Governorate, to study the effect of foliar spray with potassium silicate at different concentrations on vegetative growth, yield and its components, fruit quality and storability of cucumber fruits (Cucumus sativus L.) Hisham $\mathrm{F}_{1}$ hybrid. The results indicated that foliar spray with potassium silicate at $4 \%$ or $3 \%$ significantly increased vegetative growth parameters (plant height, number of leaves/ plant, fresh weight of plant and chlorophyll reading (SPAD) in leaves, silicon and potassium contents in the leaves, yield and its components (fruit weight and total yield / plant), physical and chemical properties of fruit and silicon and potassium contents in fruits as compared with other treatments or untreated plants (control). Potassium silicate at $4 \%$ improved storability of cucumber fruit (reduced weight loss, color change and maintained fruit firmness, TSS and V.C) and exhibited good appearance after 15 days of storage at $10^{\circ} \mathrm{C}$.
\end{abstract}

\section{Introduction}

Cucumber (Cucumus sativus L.) is one of the most important and popular vegetable crops belonging to the family cucurbitaceae. Cucumber is a primary source of vitamins and minerals for human body but its caloric and nutritional value is very low (Wang and Qi, 1997).To improve the cucumber fruits quality and quantity in the field, maintain their quality after harvest and increase their shelf life, several investigations have been conducted on pre and postharvest treatments. Potassium silicate is a source of highly soluble silicon and potassium. It is used in agricultural production systems primarily as a silica amendment and has the added benefit of supplying small amounts of potassium. Silicon deposited in the walls of epidermal cells after absorption by plants, contributes considerably to stem strength. Silicon is not much mobile element in plants (Epstein, 1999). The role of silicon in plant biology is to reduce multiple stresses including biotic and abiotic stresses. It is also known to increase drought tolerance in plants by maintaining plant water balance, photosynthetic activity, erectness of leaves and structure of xylem vessels under high transpiration rates (Epstein, 2001). Silicon may enhance soil fertility, and uptake of water and other nutrient elements, improve disease and pest resistance and plant growth, photosynthesis and yield (Samuels et al., 1993). Also, Gorecki and DanieskiBusch (2009) suggested that foliar spray with potassium silicate of cucumber plants increased yield which was enhanced with the number of fruits per plant. In addition Jarosz (2013) detected significantly more silicon in leaves and fruits of cucumber plants treated with silicon. It is also improves fruit quality such as increase fruit weight, fruit dimensions and fruit firmness (Ibrahim and Al- Wasfy, 2014). Potassium silicate could improve storability of fruits (Afifi, 2016) as they found that foliar spray with potassium silicate at $2000 \mathrm{ppm}$ improved storability of strawberry fruits and exhibited good appearance with no decay after 12 days at $0^{\circ} \mathrm{C}+2$ days at $10^{\circ} \mathrm{C}$.

Therefore, the objectives of this study was to investigate the effect of foliar spray with potassium silicate at different concentrations on vegetative growth, yield and its components, fruit quality and storability of cucumber.

\section{Materials and Methods}

The experiment was carried out under plastic house conditions during autumn seasons of 2016 and 2017 at the Agricultural Experiment Station, Faculty of Agriculture, Cairo University and Laboratory of Handling of Vegetable Department, Horticulture Research Institute in Giza Governorate to study the effect of foliar spray with potassium silicate on vegetative growth, yield and its components, fruit quality and storability of cucumber fruits (Сиситus sativus L.) Hisham $\mathrm{F}_{1}$ hybrid. The physical and chemical properties of the clay loam soil under study (Table1) were determined at Soil and water Research Institute, Agriculture Research Center. Seeds were sown in nursery on $9^{\text {th }}$ and $12^{\text {th }}$ of September 2016 and 2017, respectively. Seedlings were transplanted on $24^{\text {th }}$ and $27^{\text {th }}$ of September in the first and second seasons, respectively. The plastic house was $40 \mathrm{~m}$ long and $8 \mathrm{~m}$ width $\left(320 \mathrm{~m}^{2}\right)$ and divided into five beds, each $1 \mathrm{~m}$ wide and $40 \mathrm{~m}$ long. The experiment occupied three beds. Seedlings were sown in hills on two sides of the bed with $50 \mathrm{~cm}$ apart. Potassium 
Silicate $(1 \%, 2 \%, 3 \%$ or $4 \%)$ were applied as foliar spray beside untreated control (spraying with distilled water). The treatments were applied three times during the growth period of cucumber plants at 20, 30 and 40 days after transplanting. The previous treatments were arranged in complete randomized block design with three replicates. The area of each plot was $5 \mathrm{~m}^{2}$ with 20 plants. Each replicate consisted of one plot. The recommended agricultural practices for commercial cucumber production, i.e., drip irrigation, fertilization and weed control were followed according to Ministry of Agriculture recommendations.

Table 1. Physical and chemical characteristics of experimental soil as average of both seasons 2016 and 2017.



Data were recorded as follow:

A-Vegetative growth:

A representative sample of 5 plants was chosen at random, 45 days after sowing, from each experimental plot for measuring plant growth parameters, viz., plant height, number of leaves per plant and plant fresh weight. Chlorophyll reading of the sixth mature leaf was measured in SPAD unit, where SPAD $=10 \mathrm{mg}$ chlorophyll $/ \mathrm{g}$ fresh weight using digital chlorophyll meter (Model Minolta chlorophyll meter SPAD-502) which is presented by SPAD value. Average of 3 measurements from different spots of a single leave was considered.

Silicon and potassium contents in leaves were determined by ICP atomic emission spectrometer (Stefánsson et al., 2007).

\section{B-Yield and its components:}

At harvesting time (50 days from sowing), cucumber fruits were picked at the proper stage of maturity through the harvesting period till the second week of December for estimation of yield parameters, viz., fruit weight and total yield/plant (determined for all pickings and calculated as total fresh weight of fruits).

\section{C- Fruit quality:}

A random sample of 30 fruits from each replicate was taken at harvest and the following characters were measured: fruit length, fruit diameter, fruit firmness, color change ( $\mathrm{L}$ and $\mathrm{h}^{\circ}$ value), vitamin $\mathrm{C}$ content and total soluble solids \%. Silicon and potassium contents in fruits were determined as previously mentioned.

\section{Storage experiment:}

Fruits of cucumber for each treatment were harvested at the proper stage of maturity on $5^{\text {th }}$ and $8^{\text {th }}$ of November in the first and second seasons, respectively, then transferred to laboratory of Handling Of Vegetable Crops Department, Horticultural Research Institute at Giza. Samples were selected for their uniformity of size $(12-14 \mathrm{~cm}$ in length and $2.5-3 \mathrm{~cm}$ in diameter) and free of visual damage defects. All samples for pre-harvest treatments of cucumber fruits were placed in polypropylene bags $(25 \times 30 \mathrm{~cm})$ and $20 \mathrm{~mm}$ thickness. Each bag contains 6 fruits represented as experimental unit (EU). Eighteen EU were prepared for each treatment and stored at $10^{\circ} \mathrm{C}$ and $95 \%$ relative humidity $(\mathrm{RH})$. Samples were taken randomly in three replicates from each EU and were arranged in complete randomized design. Measurements were done immediately after harvest and at 3 days intervals (0, 3, 6, 9, 12 and 15days) of storage at $10^{\circ} \mathrm{C}$ for the following characteristics:

- Weight loss percentage was estimated according to the following equation:

Weight loss $\%=$ Initial weight of fruits- weight of fruits at sampling date $\times 100$

\section{Initial weight of fruits}

- General appearance was measured on score rating from 9 to 1 ,

where $9=$ excellent, $7=$ good, $5=$ fair, $3=$ poor and 1 $=$ unsalable.

- Surface color was measured on two sides of each fruit by using Tistimulus Hunter Colorimeter Minolta, Ramsey, N.J.(Model Dp 9000 which measured $\mathrm{L}^{*}$ value and hue angle) (McGuire,1992).

- Fruit firmness was measured by a hand pressure tester (Italian model) expressed in $\mathrm{kg} / \mathrm{cm}^{2}$. 
-Total soluble solids percentage (TSS) was determined by using refractometer according to AOAC (2000).

-Ascorbic acid content (mg /100 g fruit fresh weight) was determined by titration method using 2, 6 dichloro-phenole-endo-phenole (AOAC, 2000).

Data were subjected to the statistical analysis according to Snedecor and Cochran (1980).

\section{Results and Discussion}

\section{Vegetative growth:}

Data in Table (2) show that cucumber plants treated with all concentrations of potassium silicate significantly increase in vegetative growth parameters (plant height, number of leaves/plant and fresh weight of plant) and chlorophyll reading (SPAD in leaves) as compared with untreated plants (control). The highest rates of these variables were found at $3 \%$ or $4 \%$ concentrations. In other words, application of lower concentrations of potassium silicate $(1 \%$ or $2 \%)$ reduced plant height, number of leaves/plant and chlorophyll reading (SPAD) as higher concentrations (3\% or $4 \%$ ). On the other hand, the lowest values in this respect were recorded in untreated plants (control). These results were true in the two seasons and in agreement with those of Miyake and Takahashi (1983) and Wolff et al.(2008) on cucumber. The increase in cucumber plant growth by foliar spray of potassium silicate may be related to enhanced tissue elasticity and symplastic water volume which were associated with all enlargement and plant growth (Emadian and Newton, 1989). Also the favorable effect of silicon on crop plants seems to originate from reinforcement of the cell walls due to deposition of silicon in the cell wall in the form of amorphous silica (Epstein, 1999). Furthermore, silicon has also been shown to interact with the uptake of other nutrient elements and increase plant growth by reducing the toxicity of micronutrient elements such as iron, zinc, copper and manganese when present in excess levels in the soil (Epstein et al., 1988). The increment in chlorophyll content caused by foliar spray of potassium silicate may be due to the high uptake of magnesium in the leaf which in turn, increase chlorophyll content in the leaves as found by Lalithya et al. (2014).

Table 2. Effect of foliar spray with potassium silicate on plant height, plant fresh weight, no. of leaves / plant and chlorophyll reading in leaves of cucumber plants in 2016 and 2017 seasons.

\begin{tabular}{|c|c|c|c|c|c|c|c|c|c|}
\hline \multirow{2}{*}{\multicolumn{2}{|c|}{ Treatments }} & \multicolumn{2}{|c|}{ plant height $(\mathrm{cm})$} & \multirow{2}{*}{\multicolumn{2}{|c|}{  }} & \multirow{2}{*}{$\begin{array}{l}\text { No.of } \\
\text { plant } \\
2016\end{array}$} & \multirow{2}{*}{$\begin{array}{l}\text { leaves } \\
2017\end{array}$} & \multicolumn{2}{|c|}{$\begin{array}{l}\text { chlorophyll } \\
\text { (SPAD) }\end{array}$} \\
\hline & & 2016 & 2017 & & & & & 2016 & 2017 \\
\hline $\begin{array}{l}1 \% \\
\text { silicate } \\
2 \%\end{array}$ & $\begin{array}{l}\text { potassium } \\
\text { potassium }\end{array}$ & $188.00 \mathrm{~B}$ & $185.00 \mathrm{~B}$ & $121.50 \mathrm{~B}$ & $119.23 \mathrm{~B}$ & $21.50 \mathrm{C}$ & $20.50 \mathrm{C}$ & $23.23 \mathrm{~B}$ & $23.60 \mathrm{C}$ \\
\hline $\begin{array}{l}\text { silicate } \\
\mathbf{3 \%}\end{array}$ & potassium & $199.00 \mathrm{~B}$ & $195.00 \mathrm{~B}$ & $136.00 \mathrm{~B}$ & $128.30 \mathrm{~B}$ & $23.33 \mathrm{~B}$ & $22.33 \mathrm{~B}$ & $25.40 \mathrm{~B}$ & 27.47B \\
\hline $\begin{array}{l}\text { silicate } \\
4 \%\end{array}$ & potassium & $215.00 \mathrm{~A}$ & $213.00 \mathrm{~A}$ & $142.00 \mathrm{~A}$ & $140.00 \mathrm{~A}$ & $25.33 \mathrm{~A}$ & $24.83 \mathrm{~A}$ & $\begin{array}{l}31.00 \mathrm{~A} \\
31.89\end{array}$ & $30.50 \mathrm{~A}$ \\
\hline silicate & & $217.30 \mathrm{~A}$ & $215.30 \mathrm{~A}$ & $144.10 \mathrm{~A}$ & $142.10 \mathrm{~A}$ & $25.70 \mathrm{~A}$ & $25.20 \mathrm{~A}$ & A & $31.39 \mathrm{~A}$ \\
\hline Control & & $170.0 \mathrm{C}$ & $166.00 \mathrm{C}$ & $103.00 \mathrm{C}$ & $97.30 \mathrm{C}$ & $18.00 \mathrm{D}$ & $16.50 \mathrm{D}$ & $19.23 \mathrm{C}$ & $20.73 \mathrm{D}$ \\
\hline
\end{tabular}

\section{Silicon and potassium contents in leaves:}

Data in Table (3) show that potassium and silicon contents in the leaf differed significantly among different concentrations of potassium silicate treatments. The higher concentration of potassium silicate $4 \%$ gave significantly the highest content of silicon and potassium in the leaves followed by $3 \%$ with significant differences between them in the two seasons. The lowest values were observed in untreated plants control. Potassium silicate as it contain potassium resulted in more uptake of potassium and silicon resulted in more accumulation of potassium and silicon in the leaf. These results are in agreement with those of Kanto et al.(2004) and Afifi, (2016) who found that foliar spray with potassium silicate of strawberry plants increased silicon content in the leaves about 2 to 24 times that in the control. They stated also that, when leaves contained more than $1.5 \%$ silicate, disease was markedly suppressed. Also, Jarosz (2013) found that foliar spray of cucumber plants with potassium silicate increased silicon content in the leaves than in the control. 
Table 3. Effect of foliar spray with potassium silicate on silicon and potassium contents in leaves of cucumber plants in 2016 and 2017 seasons.

\begin{tabular}{lllll}
\hline Treatments & Silicon $(\mathbf{p p m})$ & \multicolumn{3}{c}{ K $(\boldsymbol{\%})$} \\
& $\mathbf{2 0 1 6}$ & $\mathbf{2 0 1 7}$ & $\mathbf{2 0 1 6}$ & $\mathbf{2 0 1 7}$ \\
\hline $\mathbf{1 \%}$ potassium silicate & $190.30 \mathrm{D}$ & $187.30 \mathrm{D}$ & $1.41 \mathrm{D}$ & $1.57 \mathrm{C}$ \\
$\mathbf{2 \%}$ potassium silicate & $230.10 \mathrm{C}$ & $227.10 \mathrm{C}$ & $1.64 \mathrm{C}$ & $1.89 \mathrm{~B}$ \\
$\mathbf{3 \%}$ potassium silicate & $270.30 \mathrm{~B}$ & $268.30 \mathrm{~B}$ & $1.93 \mathrm{~B}$ & $1.95 \mathrm{~B}$ \\
$\mathbf{4 \%}$ potassium silicate & $310.20 \mathrm{~A}$ & $308.20 \mathrm{~A}$ & $2.15 \mathrm{~A}$ & $2.22 \mathrm{~A}$ \\
Control & $150.20 \mathrm{E}$ & $127.30 \mathrm{E}$ & $1.05 \mathrm{E}$ & $1.19 \mathrm{D}$ \\
\hline
\end{tabular}

Means in the same column having the same letter are not significantly different at 0.05 level by Duncan's multiple rang test.

\section{Yield and its components:}

Data in Table (4) reveal that cucumber plants treated with all concentrations of potassium silicate had significantly increased fruit weight and total yield/ plant compared to untreated plants (control). However, plants treated with the higher concentrations $(4 \%$ or $3 \%$ ) of potassium silicate were the most favorable treatments for enhancing fruit weight and total yield/plant with no significant difference between them for fruit weight. The lower concentrations $(1 \%$ or $2 \%$ ) were less effective in this concern. The lowest values in this respect were recorded in the untreated plants (control). These results are in agreement with those of Samules et al. (1993), Miyake and Takahashi (1983) and Gorecki and Danieski-Busch (2009) on cucumber and may be due to that silicon increases the photosynthetic efficiency of the plant, resulting in greater accumulation of solids in leaf tissues. These photo assimilate can be translocated to the fruits, which are strong metabolic drains, it may be one of the factors responsible for the increase of plant productivity (AlAghabary et al., 2004). Furthermore, silicon might help in cell division, more nutrient and water uptake and resulted in production of more number of fruits ( Samules et al.,1993, Miyake and Takahashi, 1983 and Gorecki and Danieski- Busch, 2009). Potassium silicate had positive effect on growth and yield. Increased yield might have attributed due to increased photosynthetic activity of plant, water metabolism, chlorophyll content, more formation of carbohydrates, membrane lipid peroxidation, protective enzymes under drought condition and more uptake of essential nutrients Miyake and Takahashi (1983). Similar results were noticed by Nesreen et al. (2011) in beans and Ma (2004) in cucumber.

Table 4. Effect of foliar spray with potassium silicate on yield and its components of cucumber fruits in 2016 and 2017 seasons.

\begin{tabular}{lllll}
\hline \multirow{2}{*}{ Treatments } & fruit weight $(\mathbf{g})$ & \multicolumn{2}{c}{ Total yield / plant (kg) } \\
& $\mathbf{2 0 1 6}$ & $\mathbf{2 0 1 7}$ & $\mathbf{2 0 1 6}$ & $\mathbf{2 0 1 7}$ \\
\hline $\mathbf{1 \%}$ potassium silicate & $82.13 \mathrm{~B}$ & $79.13 \mathrm{~B}$ & $3.12 \mathrm{D}$ & $2.82 \mathrm{D}$ \\
$\mathbf{2 \%}$ potassium silicate & $84.19 \mathrm{~B}$ & $81.60 \mathrm{~B}$ & $3.68 \mathrm{C}$ & $3.38 \mathrm{C}$ \\
$\mathbf{3 \%}$ potassium silicate & $87.50 \mathrm{~A}$ & $85.50 \mathrm{~A}$ & $3.95 \mathrm{~B}$ & $3.75 \mathrm{~B}$ \\
$\mathbf{4 \%}$ potassium silicate & $88.00 \mathrm{~A}$ & $86.00 \mathrm{~A}$ & $4.12 \mathrm{~A}$ & $3.92 \mathrm{~A}$ \\
Control & $77.34 \mathrm{C}$ & $73.34 \mathrm{C}$ & $2.80 \mathrm{E}$ & $2.40 \mathrm{E}$ \\
\hline
\end{tabular}

Means in the same column having the same letter are not significantly different at 0.05 level by Duncan's multiple rang test.

\section{Fruit quality:}

Data in Tables (5 and 6) show that spraying cucumber plants with all concentrations of potassium silicate significantly increased their fruit quality expressed as physical properties (fruit length and fruit firmness) and chemical properties (ascorbic acid content) compared with fruits obtained from untreated plants. In this respect, potassium silicate at $4 \%$ were the most effective treatment for improving fruit quality, followed by potassium silicate at $3 \%$ with no significant differences between them of these characters except fruit firmness. The lowest values of these characters resulted by untreated plants.
However, concerning fruit diameter and TSS\%, there were no significant differences between all concentrations of potassium silicate and the control except TSS\% in the first season. Silicon might help in improving fruit quality due to the improvement of growth of cucumber plants in response to foliar application of potassium silicate which may result in improving quality of cucumber fruit such as length, ascorbic acid, TSS, firmness (Voogt and Sonneveld, 2001). The favorable effect of silicon on fruit firmness may be due to that silicon increases mechanical strength of the cell wall (Marodin et al., 2014). 
Table 5. Effect of foliar spray with potassium silicate on physical properties of cucumber fruits in 2016 and 2017 seasons.

\begin{tabular}{lllllll}
\hline Treatments & \multicolumn{2}{l}{ Fruit length $(\mathbf{c m})$} & \multicolumn{2}{l}{ Fruit diameter $(\mathbf{c m})$} & \multicolumn{2}{l}{ Firmness $\left(\mathbf{K g} / \mathbf{c m}^{\mathbf{2}}\right)$} \\
& $\mathbf{2 0 1 6}$ & $\mathbf{2 0 1 7}$ & $\mathbf{2 0 1 6}$ & $\mathbf{2 0 1 7}$ & $\mathbf{2 0 1 6}$ & $\mathbf{2 0 1 7}$ \\
\hline $\mathbf{1 \%}$ potassium silicate & $13.70 \mathrm{~B}$ & $12.62 \mathrm{~B}$ & $2.00 \mathrm{~A}$ & $2.68 \mathrm{AB}$ & $4.32 \mathrm{D}$ & $4.12 \mathrm{D}$ \\
$\mathbf{2 \%}$ potassium silicate & $13.80 \mathrm{~B}$ & $12.89 \mathrm{~B}$ & $2.920 \mathrm{~A}$ & $2.70 \mathrm{~A}$ & $4.93 \mathrm{C}$ & $4.73 \mathrm{C}$ \\
$\mathbf{3 \%}$ potassium silicate & $14.38 \mathrm{~A}$ & $13.88 \mathrm{~A}$ & $2.950 \mathrm{~A}$ & $2.75 \mathrm{~A}$ & $5.74 \mathrm{~B}$ & $5.64 \mathrm{~B}$ \\
$\mathbf{4 \%}$ potassium silicate & $14.50 \mathrm{~A}$ & $14.00 \mathrm{~A}$ & $2.960 \mathrm{~A}$ & $2.76 \mathrm{~A}$ & $5.82 \mathrm{~A}$ & $5.72 \mathrm{~A}$ \\
Control & $13.00 \mathrm{C}$ & $11.50 \mathrm{C}$ & $2.85 \mathrm{~A}$ & $2.65 \mathrm{AB}$ & $3.97 \mathrm{E}$ & $3.41 \mathrm{E}$ \\
\hline
\end{tabular}

Means in the same column having the same letter are not significantly different at 0.05 level by Duncan's multiple rang test.

Table 6. Effect of foliar spray with potassium silicate on chemical properties of cucumber fruits in 2016 and 2017 seasons.

\begin{tabular}{lllll}
\hline \multirow{2}{*}{ Treatments } & T.S.S $(\boldsymbol{\%})$ & & \multicolumn{2}{c}{ Ascorbic acid (mg/100g F.W.) } \\
& $\mathbf{2 0 1 6}$ & $\mathbf{2 0 1 7}$ & $\mathbf{2 0 1 6}$ & $\mathbf{2 0 1 7}$ \\
\hline $\mathbf{1 \%}$ potassium silicate & $3.40 \mathrm{AB}$ & $2.80 \mathrm{~A}$ & $104.00 \mathrm{~B}$ & $101.00 \mathrm{~B}$ \\
$\mathbf{2 \%}$ potassium silicate & $3.70 \mathrm{AB}$ & $3.10 \mathrm{~A}$ & $106.30 \mathrm{~B}$ & $104.10 \mathrm{~B}$ \\
$\mathbf{3 \%}$ potassium silicate & $3.90 \mathrm{~A}$ & $3.50 \mathrm{~A}$ & $113.30 \mathrm{~A}$ & $110.30 \mathrm{~A}$ \\
$\mathbf{4 \%}$ potassium silicate & $3.81 \mathrm{~A}$ & $3.41 \mathrm{~A}$ & $115.10 \mathrm{~A}$ & $112.10 \mathrm{~A}$ \\
Control & $3.13 \mathrm{~B}$ & $2.53 \mathrm{~A}$ & $100.1 \mathrm{C}$ & $94.20 \mathrm{C}$ \\
\hline
\end{tabular}

Means in the same column having the same letter are not significantly different at 0.05 level by Duncan's multiple rang test.

\section{Silicon and potassium contents in fruits:}

Data in Table (7) show that cucumber fruits obtained from plants sprayed with all concentrations of potassium silicate had significantly higher silicon and potassium contents as compared with fruits which obtained from untreated plants (control). However, the higher concentration of potassium silicate $(4 \%)$ gave significantly the highest contents of silicon and potassium in the fruits. These results are in agreement with those obtained by Jarosz
(2013) on cucumber who found significantly more silicon in fruits of cucumber treated plants with silicon compared to fruits obtained from untreated plants. In addition Gorecki and Danieski-Busch (2009) found that foliar spray of cucumber plants with potassium silicate, and observed that leaves accumulated several-fold more silicon than fruits and that silicates amended growing media caused higher silicon accumulation in leaves and fruits.

Table 7. Effect of foliar spray with potassium silicate on silicon and potassium contents of cucumber fruits in 2016 and 2017 seasons.

\begin{tabular}{lcccc}
\hline \multirow{2}{*}{ Treatments } & \multicolumn{2}{c}{ Silicon (ppm) } & \multicolumn{2}{c}{ K (\%) } \\
& $\mathbf{2 0 1 6}$ & $\mathbf{2 0 1 7}$ & $\mathbf{2 0 1 6}$ & $\mathbf{2 0 1 7}$ \\
\hline $\mathbf{1 \%}$ potassium silicate & $160.20 \mathrm{D}$ & $157.20 \mathrm{D}$ & $1.36 \mathrm{D}$ & $1.62 \mathrm{C}$ \\
$\mathbf{2 \%}$ potassium silicate & $192.30 \mathrm{C}$ & $189.30 \mathrm{C}$ & $1.59 \mathrm{C}$ & $1.94 \mathrm{~B}$ \\
$\mathbf{3 \%}$ potassium silicate & $230.30 \mathrm{~B}$ & $228.30 \mathrm{~B}$ & $1.89 \mathrm{~B}$ & $1.96 \mathrm{~B}$ \\
$\mathbf{4 \%}$ potassium silicate & $270.00 \mathrm{~A}$ & $268.30 \mathrm{~A}$ & $2.11 \mathrm{~A}$ & $2.22 \mathrm{~A}$ \\
Control & $120.40 \mathrm{E}$ & $116.40 \mathrm{E}$ & $0.99 \mathrm{E}$ & $1.19 \mathrm{D}$ \\
\hline
\end{tabular}

Means in the same column having the same letter are not significantly different at 0.05 level by Duncan's multiple rang test.

\section{Storage experiment:}

Weight loss percentage:

Data in Table (8) show that weight loss percentage of cucumber fruits increased considerably and consistently with the prolongation of storage period. The weight loss is a natural consequence of the catabolism of horticultural products. The loss in weight may be attributes to respiration and other senescence related metabolic processes during storage (Wills et al., 1998). Similar results were reported by Rageh and Abou-Elwafa (2017). Concerning the effect of pre-harvest treatments, data reveal that cucumber fruits obtained from plants treated with all pre-harvest treatments retained their weight during storage as compared with those obtained from untreated plants (control), however, fruits obtained from plants treated with potassium silicate at $3 \%$ or $4 \%$ surpassed those fruits obtained from the other treatments or untreated control in minimizing fruit weight loss percentage during storage with no significant differences between them in the two seasons. Cucumber fruits obtained from the other concentrations ( $1 \%$ or $2 \%$ ) were less effected in reducing the loss of weight percentage. On the contrary, fruits obtained from untreated plants gave the highest values of weight loss \%. These results were true in the two seasons and in agreement with results of Afifi (2016) on strawberry. The benefit effect of potassium silicate on reducing weight loss percentage in fruits during storage may 
be attributed to that Si treatment covers fruit stomata with a $\mathrm{Si}$ layer, it reduces fruit respiration and concomitantly results in decreases weight loss in $\mathrm{Si}$ treatments, therefore, it could be positively associated with delaying fruit weight loss by maintaining moisture (Hammash and El Assi, 2007).Furthermore, silicon reduced membrane permeability (Laing et al.,1993) and increased membrane stability and integrity (Agarie et al., 1998) due to endogenous silicon. Silicon might help in improving fruit quality due to suppression of respiration and reduction in ethylene evolution and thus minimized physiological loss in weight of the fruit.

In general, the interaction between pre-harvest treatments and storage period was significant in both seasons. After 15 days of storage, cucumber fruits obtained from plants treated with potassium silicate at $3 \%$ or $4 \%$ showed the least weight 10 ss $\%$ with significant differences between them, while those obtained from untreated plants gave the highest values of weight loss percentages.

Table 8. Effect of foliar spray with potassium silicate on weight loss $\%$ of cucumber fruits during storage at $10^{\circ} \mathrm{C}$ in 2016 and 2017 seasons.

\begin{tabular}{|c|c|c|c|c|c|c|c|}
\hline \multirow{3}{*}{ Treatments } & \multicolumn{6}{|c|}{ Storage period in days } & \multirow{3}{*}{ Mean } \\
\hline & \multicolumn{6}{|c|}{ season 2016} & \\
\hline & Start & 3 & 6 & 9 & 12 & 15 & \\
\hline $1 \%$ potassium silicate & $0.00 \mathrm{M}$ & $0.27 \mathrm{~L}$ & $0.84 \mathrm{H}$ & $1.23 \mathrm{FG}$ & $1.98 \mathrm{D}$ & $2.40 \mathrm{~B}$ & $1.12 \mathrm{~B}$ \\
\hline $2 \%$ potassium silicate & $0.00 \mathrm{M}$ & $0.26 \mathrm{~L}$ & $0.85 \mathrm{H}$ & $1.15 \mathrm{G}$ & $1.65 \mathrm{E}$ & $2.10 \mathrm{D}$ & $1.00 \mathrm{C}$ \\
\hline $3 \%$ potassium silicate & $0.00 \mathrm{M}$ & $0.20 \mathrm{~L}$ & $0.65 \mathrm{JK}$ & $0.55 \mathrm{~K}$ & $1.30 \mathrm{~F}$ & $1.62 \mathrm{E}$ & $0.72 \mathrm{D}$ \\
\hline $4 \%$ potassium silicate & $0.00 \mathrm{M}$ & $0.22 \mathrm{~L}$ & $0.70 \mathrm{IJ}$ & $0.82 \mathrm{HI}$ & $1.31 \mathrm{~F}$ & $1.30 \mathrm{~F}$ & $0.73 \mathrm{D}$ \\
\hline Control & $0.00 \mathrm{M}$ & $0.32 \mathrm{~L}$ & $0.94 \mathrm{H}$ & $1.61 \mathrm{E}$ & $2.23 \mathrm{C}$ & $2.84 \mathrm{~A}$ & $1.32 \mathrm{~A}$ \\
\hline Mean & 0.00 F & $0.25 \mathrm{E}$ & $0.80 \mathrm{D}$ & $1.07 \mathrm{C}$ & $1.69 \mathrm{~B}$ & $2.05 \mathrm{~A}$ & \\
\hline \multicolumn{8}{|c|}{ season 2017} \\
\hline $1 \%$ potassium silicate & $0.00 \mathrm{O}$ & $0.22 \mathrm{MN}$ & $0.80 \mathrm{HI}$ & $1.17 \mathrm{FG}$ & $1.93 \mathrm{D}$ & $2.34 \mathrm{~B}$ & $1.08 \mathrm{~B}$ \\
\hline $2 \%$ potassium silicate & $0.00 \mathrm{O}$ & $0.21 \mathrm{MN}$ & $0.81 \mathrm{HI}$ & $1.09 \mathrm{G}$ & $1.60 \mathrm{E}$ & $2.04 \mathrm{D}$ & $0.96 \mathrm{C}$ \\
\hline $3 \%$ potassium silicate & $0.00 \mathrm{O}$ & $0.15 \mathrm{~N}$ & $0.61 \mathrm{~K}$ & $0.49 \mathrm{~L}$ & $1.25 \mathrm{~F}$ & $1.56 \mathrm{E}$ & $0.68 \mathrm{D}$ \\
\hline $4 \%$ potassium silicate & $0.00 \mathrm{O}$ & $0.17 \mathrm{MN}$ & $0.66 \mathrm{JK}$ & $0.76 \mathrm{IJ}$ & $1.26 \mathrm{~F}$ & $1.24 \mathrm{~F}$ & $0.68 \mathrm{D}$ \\
\hline Control & $0.00 \mathrm{O}$ & $0.27 \mathrm{M}$ & $0.90 \mathrm{H}$ & $1.55 \mathrm{E}$ & $2.18 \mathrm{C}$ & $2.78 \mathrm{~A}$ & $1.28 \mathrm{~A}$ \\
\hline Mean & 0.00 F & $0.20 \mathrm{E}$ & $0.76 \mathrm{D}$ & $1.01 \mathrm{C}$ & $1.64 \mathrm{~B}$ & $1.99 \mathrm{~A}$ & \\
\hline
\end{tabular}

Means in the same column having the same letter are not significantly different at 0.05 level by Duncan's multiple rang test.

\section{General appearance:}

Data in Table (9) indicate that general appearance of cucumber fruits decreased with the prolongation of storage period. Similar results were reported by Shehata et al. (2009) on cucumber. The decrease of general appearance of cucumber fruits during storage might be due to shriveling, pitting, color change of fruits and decay (Shehata et al., 2009 and Ragah and Abou-Elwafa, 2017).Concerning the effect of preharvest treatments, general appearance of cucumber fruits obtained from all concentrations of potassium silicate treatments were better than those obtained from untreated plants during storage. In other words, these treatments gave the highest score of appearance, while untreated control ones obtained the lowest values in this concern. However, cucumber fruits obtained from plants treated with potassium silicate at $3 \%$ or $4 \%$ were the most effective treatments for maintaining general appearance compared with the other treatments or untreated control. These results are true in the two seasons and in agreement with those of Afifi (2016).

In general, there were significant differences between pre-harvest treatments and storage period in general appearance. Cucumber fruits obtained from plants treated with potassium silicate at $3 \%$ or $4 \%$ did not exhibit any changes in their appearance till 12 days of storage and showed good appearance up to 15 days, meanwhile, those treated with potassium silicate at $2 \%$ recorded good appearance after 12 days of storage. However, fruits obtained from untreated plants dropped to poor level at 15 days of storage, indicating the absence of freshness and hardly acceptable or unacceptable appearance for marketing. These results are in agreement with those obtained by Tarabih et al. (2014) who found that potassium silicate increased the concentration of antifungal compounds and/ or the enzyme PAL to be able to increase the concentration of phenolic compounds present at later ripening stages in order to decrease decay incidence and increase the shelf life of apple fruits. Also, Kaluwa et al. (2010) found that the main effect of silicon application lies in suppression of respiration and ethylene production and increases antioxidant and total phenolics accumulation in avocado fruit, thereby, increasing the stress relieving ability of the fruit, producing fruit with a higher ability to withstand long-term storage. 
Table 9. Effect of foliar spray with potassium silicate on general appearance score of cucumber fruits during storage at $10^{\circ} \mathrm{C}$ in 2016 and 2017 seasons.

\begin{tabular}{|c|c|c|c|c|c|c|c|}
\hline \multirow{3}{*}{ Treatments } & \multicolumn{6}{|c|}{ Storage period in days } & \multirow{3}{*}{ Mean } \\
\hline & \multicolumn{6}{|c|}{ season 2016} & \\
\hline & Start & 3 & 6 & 9 & 12 & 15 & \\
\hline $1 \%$ potassium silicate & $9.00 \mathrm{~A}$ & $9.00 \mathrm{~A}$ & $9.00 \mathrm{~A}$ & $7.67 \mathrm{BC}$ & $6.33 \mathrm{D}$ & $4.33 \mathrm{E}$ & $7.56 \mathrm{~B}$ \\
\hline $2 \%$ potassium silicate & $9.00 \mathrm{~A}$ & $9.00 \mathrm{~A}$ & $9.00 \mathrm{~A}$ & $7.67 \mathrm{BC}$ & $7.00 \mathrm{CD}$ & $5.67 \mathrm{D}$ & $7.89 \mathrm{~B}$ \\
\hline $3 \%$ potassium silicate & $9.00 \mathrm{~A}$ & $9.00 \mathrm{~A}$ & $9.00 \mathrm{~A}$ & $9.00 \mathrm{~A}$ & $8.33 \mathrm{AB}$ & $7.00 \mathrm{CD}$ & $8.56 \mathrm{~A}$ \\
\hline $4 \%$ potassium silicate & $9.00 \mathrm{~A}$ & $9.00 \mathrm{~A}$ & $9.00 \mathrm{~A}$ & $9.00 \mathrm{~A}$ & $8.33 \mathrm{AB}$ & $7.00 \mathrm{CD}$ & $8.56 \mathrm{~A}$ \\
\hline Control & $9.00 \mathrm{~A}$ & $9.00 \mathrm{~A}$ & $7.00 \mathrm{CD}$ & $6.33 \mathrm{D}$ & $4.33 \mathrm{E}$ & $2.33 \mathrm{~F}$ & $6.33 \mathrm{C}$ \\
\hline \multirow[t]{2}{*}{ Mean } & $9.00 \mathrm{~A}$ & $9.00 \mathrm{~A}$ & $8.60 \mathrm{~A}$ & $7.93 \mathrm{~B}$ & $6.86 \mathrm{C}$ & $5.27 \mathrm{D}$ & \\
\hline & \multicolumn{6}{|c|}{ season 2017} & \\
\hline $1 \%$ potassium silicate & $9.00 \mathrm{~A}$ & $9.00 \mathrm{~A}$ & $9.00 \mathrm{~A}$ & $7.00 \mathrm{~B}$ & $6.33 \mathrm{C}$ & $4.33 \mathrm{C}$ & $7.44 \mathrm{~B}$ \\
\hline $2 \%$ potassium silicate & $9.00 \mathrm{~A}$ & $9.00 \mathrm{~A}$ & $9.00 \mathrm{~A}$ & $8.33 \mathrm{~A}$ & $7.00 \mathrm{~B}$ & $4.33 \mathrm{C}$ & $7.78 \mathrm{~B}$ \\
\hline $3 \%$ potassium silicate & $9.00 \mathrm{~A}$ & $9.00 \mathrm{~A}$ & $9.00 \mathrm{~A}$ & $9.00 \mathrm{~A}$ & $8.33 \mathrm{~A}$ & $7.00 \mathrm{~B}$ & $8.56 \mathrm{~A}$ \\
\hline $4 \%$ potassium silicate & $9.00 \mathrm{~A}$ & $9.00 \mathrm{~A}$ & $9.00 \mathrm{~A}$ & $9.00 \mathrm{~A}$ & $8.33 \mathrm{~A}$ & $7.00 \mathrm{~B}$ & $8.56 \mathrm{~A}$ \\
\hline Control & $9.00 \mathrm{~A}$ & $9.00 \mathrm{~A}$ & $7.00 \mathrm{~B}$ & $6.33 \mathrm{~B}$ & $3.00 \mathrm{D}$ & $1.00 \mathrm{E}$ & $5.89 \mathrm{C}$ \\
\hline Mean & $9.00 \mathrm{~A}$ & $9.00 \mathrm{~A}$ & 8.60 B & $7.93 \mathrm{C}$ & $6.60 \mathrm{D}$ & $4.73 \mathrm{E}$ & \\
\hline
\end{tabular}

Means in the same column having the same letter are not significantly different at 0.05 level by Duncan's multiple rang test.

\section{Color:}

The color of cucumber fruits is one of the most important quality factors of fresh cucumber for consumer preference. Color was measured recording lightness ( $\mathrm{L}$ value) and hue angle $\mathrm{h}^{\mathrm{o}}$ represent according to in a standardized color space. The results in Table (10) showed that there was a significant decrease in $\mathrm{L}$ value with increasing storage period for all pre-harvest treatments or control, showing darker fruits. These results were true in the two seasons and in agreement with those of Hiorse (1985) and Ragah and Abou El-wafa (2017).
Concerning the effect of pre-harvest treatments, cucumber fruits obtained from plants treated with potassium silicate at $3 \%$ or $4 \%$ had significantly higher L values indicating lighter fruits with no significant differences between them during cold storage in the two seasons, while those obtained from untreated plants had darker color (low L value). Potassium silicate at $1 \%$ or $2 \%$ were less effective in this concern. The reduction of color development in cucumber fruits treated with potassium silicate could be attributed to the slow rate of respiration and reduced ethylene production, thus delaying color changes (Hammash and El Assi, 2007).

Table 10. Effect of foliar spray with potassium silicate on $\mathrm{L}$ value of cucumber fruits during storage at $10^{\circ} \mathrm{C}$ in 2016 and 2017 seasons.

\begin{tabular}{|c|c|c|c|c|c|c|c|}
\hline \multirow[t]{2}{*}{ Treatments } & \multicolumn{6}{|c|}{$\begin{array}{c}\text { Storage period in days } \\
\text { season } 2016\end{array}$} & \multirow[t]{2}{*}{ Mean } \\
\hline & Start & 3 & 6 & 9 & 12 & 15 & \\
\hline $1 \%$ potassium silicate & $42.62 \mathrm{CE}$ & $42.00 \mathrm{DF}$ & $41.00 \mathrm{FH}$ & $40.10 \mathrm{HI}$ & $39.10 \mathrm{IJ}$ & $37.30 \mathrm{~K}$ & $40.35 \mathrm{C}$ \\
\hline $2 \%$ potassium silicate & $43.74 \mathrm{AB}$ & $43.49 \mathrm{AC}$ & $42.09 \mathrm{DF}$ & $41.60 \mathrm{EG}$ & $40.00 \mathrm{HI}$ & $39.00 \mathrm{IJ}$ & 41.65 B \\
\hline $3 \%$ potassium silicate & $43.91 \mathrm{AB}$ & $43.52 \mathrm{AC}$ & $43.65 \mathrm{AC}$ & 42.96 BD & $41.80 \mathrm{EG}$ & $41.05 \mathrm{FH}$ & 42.81 A \\
\hline $4 \%$ potassium silicate & $44.10 \mathrm{~A}$ & $44.00 \mathrm{AB}$ & $43.57 \mathrm{AC}$ & $43.10 \mathrm{AD}$ & $42.10 \mathrm{DF}$ & $41.60 \mathrm{EG}$ & 43.08 A \\
\hline Control & 41.07 FH & $40.81 \mathrm{GH}$ & $40.00 \mathrm{HI}$ & $38.80 \mathrm{~J}$ & $37.14 \mathrm{~K}$ & $35.40 \mathrm{~L}$ & 38.87 D \\
\hline \multirow[t]{2}{*}{ Mean } & 43.09 A & $42.76 \mathrm{~A}$ & 42.06 B & $41.31 \mathrm{C}$ & 40.03 D & $38.87 \mathrm{E}$ & \\
\hline & \multicolumn{6}{|c|}{ season 2017} & \\
\hline $1 \%$ potassium silicate & $39.62 \mathrm{AE}$ & $39.00 \mathrm{AF}$ & $38.00 \mathrm{AF}$ & $37.10 \mathrm{AG}$ & $36.10 \mathrm{BG}$ & $34.30 \mathrm{EG}$ & $37.35 \mathrm{C}$ \\
\hline $2 \%$ potassium silicate & $40.74 \mathrm{AD}$ & $40.49 \mathrm{AD}$ & $39.09 \mathrm{AF}$ & $38.60 \mathrm{AF}$ & $37.00 \mathrm{AG}$ & $36.00 \mathrm{H}$ & $38.65 \mathrm{~B}$ \\
\hline $3 \%$ potassium silicate & $41.91 \mathrm{AC}$ & $41.52 \mathrm{AC}$ & $41.65 \mathrm{AC}$ & $40.96 \mathrm{AC}$ & $39.80 \mathrm{AE}$ & $39.05 \mathrm{AF}$ & 40.81 A \\
\hline $4 \%$ potassium silicate & $42.10 \mathrm{~A}$ & $42.00 \mathrm{AB}$ & $41.57 \mathrm{AC}$ & $41.10 \mathrm{AC}$ & $40.10 \mathrm{AE}$ & $39.60 \mathrm{AE}$ & 41.08 A \\
\hline Control & $37.07 \mathrm{AG}$ & $36.81 \mathrm{AG}$ & $36.00 \mathrm{CG}$ & 34.80 DG & $33.14 \mathrm{FG}$ & $31.40 \mathrm{G}$ & 34.87 D \\
\hline Mean & $40.29 \mathrm{~A}$ & $39.96 \mathrm{~A}$ & $39.26 \mathrm{AB}$ & $38.51 \mathrm{AB}$ & $37.23 \mathrm{~B}$ & $33.67 \mathrm{C}$ & \\
\hline
\end{tabular}

Means in the same column having the same letter are not significantly different at 0.05 level by Duncan's multiple rang test.

Data in Table (11) indicate significant decrease in hue angle $h^{\circ}$ values of cucumber fruits was noticed with prolongation of storage period in the two seasons. The color of cucumber fruits show much color deterioration after 15 days of storage, these results were true in the two seasons and may be attributed to a gradual destruction by chlorophylls activity and transformation of chloroplast to chromoplast (Dong et al., 2004).

Concerning the effect of pre-harvest treatments, data show that cucumber fruits obtained from all preharvest treatments were of significantly had higher hue angle values as compared with untreated control, however fruit obtained from potassium silicate at $4 \%$ was the most effective treatments in reducing the loss 
of hue angle value indicating that fruits retained more green color during storage. While the lowest hue angle values were detected in the untreated control indicating that fruits had less green color. Cucumber fruits obtained from plants treated with potassium silicate at $1 \%$ or $2 \%$ were less effective in maintaining the green color during storage. These results were true in the two seasons and in agreement with those of Afifi (2016). The favorable effect of potassium silicate in reducing color change may be due to that potassium silicate reduced ethylene production (Jamali and Rahemi, 2011), thus lower chlorophylls enzyme action and chlorophyll degradation, so maintained green color of cucumber fruits.

Table 11. Effect of foliar spray with potassium silicate on hue angle $\left(\mathrm{h}^{\circ}\right)$ of cucumber fruits during storage at $10^{\circ} \mathrm{C}$ in 2016 and 2017 seasons.

\begin{tabular}{|c|c|c|c|c|c|c|c|}
\hline \multirow{3}{*}{ Treatments } & \multicolumn{6}{|c|}{ Storage period in days } & \multirow{3}{*}{ Mean } \\
\hline & \multicolumn{6}{|c|}{ season 2016} & \\
\hline & Start & 3 & 6 & 9 & 12 & 15 & \\
\hline $1 \%$ potassium silicate & $123.60 \mathrm{H}$ & $121.20 \mathrm{~J}$ & $119.20 \mathrm{~L}$ & $115.40 \mathrm{O}$ & $112.40 \mathrm{P}$ & $108.20 \mathrm{R}$ & 116.70 D \\
\hline $2 \%$ potassium silicate & 127.10 D & $125.40 \mathrm{~F}$ & $124.20 \mathrm{G}$ & $122.10 \mathrm{I}$ & $120.50 \mathrm{~K}$ & $118.40 \mathrm{M}$ & $123.00 \mathrm{C}$ \\
\hline $3 \%$ potassium silicate & $130.40 \mathrm{~B}$ & $127.60 \mathrm{D}$ & $126.30 \mathrm{E}$ & $125.20 \mathrm{~F}$ & $124.30 \mathrm{G}$ & $\begin{array}{l}122.30 \mathrm{I} \\
124.10\end{array}$ & 126.00 B \\
\hline $4 \%$ potassium silicate & $131.20 \mathrm{~A}$ & $128.40 \mathrm{C}$ & $127.40 \mathrm{D}$ & $126.40 \mathrm{E}$ & $125.40 \mathrm{~F}$ & $\mathrm{GH}$ & 127.20 A \\
\hline Control & $119.40 \mathrm{~L}$ & $117.40 \mathrm{~N}$ & $115.20 \mathrm{O}$ & $111.40 \mathrm{Q}$ & $108.20 \mathrm{R}$ & $104.30 \mathrm{~S}$ & $112.70 \mathrm{E}$ \\
\hline Mean & $126.30 \mathrm{~A}$ & 124.00 B & $122.50 \mathrm{C}$ & $120.10 \mathrm{D}$ & $118.20 \mathrm{E}$ & $115.50 \mathrm{~F}$ & \\
\hline \multicolumn{8}{|c|}{ season 2017} \\
\hline $1 \%$ potassium silicate & $120.60 \mathrm{I}$ & $118.20 \mathrm{~K}$ & $116.20 \mathrm{M}$ & $112.40 \mathrm{P}$ & $109.40 \mathrm{R}$ & $105.20 \mathrm{~T}$ & $113.70 \mathrm{D}$ \\
\hline $2 \%$ potassium silicate & $124.10 \mathrm{E}$ & $122.40 \mathrm{G}$ & $121.20 \mathrm{H}$ & $119.10 \mathrm{~J}$ & $117.50 \mathrm{~L}$ & $115.40 \mathrm{~N}$ & $120.00 \mathrm{C}$ \\
\hline 3\% potassium silicate & $128.40 \mathrm{~B}$ & $125.60 \mathrm{D}$ & $124.30 \mathrm{E}$ & $123.20 \mathrm{~F}$ & $122.30 \mathrm{G}$ & $120.30 \mathrm{I}$ & 124.00 B \\
\hline $4 \%$ potassium silicate & $129.20 \mathrm{~A}$ & $126.40 \mathrm{C}$ & $125.40 \mathrm{D}$ & $124.40 \mathrm{E}$ & $123.40 \mathrm{~F}$ & $122.10 \mathrm{G}$ & $125.20 \mathrm{~A}$ \\
\hline Control & $115.40 \mathrm{~N}$ & $113.40 \mathrm{O}$ & $111.20 \mathrm{Q}$ & $107.40 \mathrm{~S}$ & $104.20 \mathrm{U}$ & $100.30 \mathrm{~V}$ & $108.70 \mathrm{E}$ \\
\hline Mean & $123.50 \mathrm{~A}$ & 121.20 B & $119.70 \mathrm{C}$ & 117.30 D & $115.40 \mathrm{E}$ & $112.70 \mathrm{~F}$ & \\
\hline
\end{tabular}

Means in the same column having the same letter are not significantly different at 0.05 level by Duncan's multiple rang test.

\section{Firmness:}

Data in Table (12) revel that significant reduction in fruit firmness had occurred by prolongation of storage period. These results are in agreement with those obtained by Shehata et al. (2009) and may be due to gradual breakdown of protopectin to water soluble lower molecular weight fractions leading to the increase in the rate of fruit softening (Wills et al., 1998).

Concerning the effect of pre-harvest treatments, data show that cucumber fruits obtained from plants treated with all used concentrations of potassium silicate had significantly greater fruit firmness as compared with untreated plants during storage, however, cucumber fruits obtained from plants treated with potassium silicate at $3 \%$ or $4 \%$ were the most effective treatments in reducing the loss of fruit firmness during storage with significant differences between them, whereas, the highest losses of fruit firmness were found in untreated plants (control).
The interaction between pre-harvest treatments and storage period was significant in the two seasons. After 15 days of storage, data reveal that cucumber fruit from plants treated with potassium silicate at $4 \%$ had significantly higher fruit firmness as compared with the other treatments or untreated control in the two seasons. These results are in agreement with those of Tarabih et al. (2014) on Anna apple fruits. Tesfay et al. (2011) reported that silicon treated fruits had lower electrolyte leakage compared with the control, possibly due to that silicon deposition between cell wall and cell membrane, maintaining a barrier against soluble leakage. Also, silicon may enhance activity of chitinases, peroxidase and polyphenol oxidases and increased formation deposition of callose and hydrogen peroxidase (Shetty et al., 2012). Silicon application improved strength and rabidity of tissue (Liang et al., 1993).

Table 12. Effect of foliar spray with potassium silicate on fruit firmness $\left(\mathrm{kg} / \mathrm{cm}^{2}\right)$ of cucumber during storage at $10^{\circ} \mathrm{C}$ in 2016 and 2017 seasons.

\section{Treatments}

$1 \%$ potassium silicate

$2 \%$ potassium silicate

$3 \%$ potassium silicate

$4 \%$ potassium silicate

\begin{tabular}{lllllll}
\multicolumn{7}{c}{$\begin{array}{c}\text { Storage period in days } \\
\text { season } \mathbf{2 0 1 6}\end{array}$} \\
Start & $\mathbf{3}$ & $\mathbf{6}$ & $\mathbf{9}$ & $\mathbf{1 2}$ & $\mathbf{1 5}$ & Mean \\
\hline $4.32 \mathrm{~J}$ & $3.80 \mathrm{~L}$ & $3.40 \mathrm{~N}$ & $3.00 \mathrm{O}$ & $2.60 \mathrm{Q}$ & $2.10 \mathrm{~S}$ & $\mathbf{3 . 2 0} \mathbf{D}$ \\
$4.93 \mathrm{~F}$ & $4.40 \mathrm{I}$ & $4.00 \mathrm{~K}$ & $3.73 \mathrm{~L}$ & $3.00 \mathrm{O}$ & $2.80 \mathrm{P}$ & $\mathbf{3 . 8 1} \mathbf{C}$ \\
$5.74 \mathrm{~B}$ & $5.50 \mathrm{D}$ & $5.00 \mathrm{~F}$ & $4.60 \mathrm{G}$ & $4.00 \mathrm{~K}$ & $3.40 \mathrm{~N}$ & $\mathbf{4 . 7 1 ~ B}$ \\
$5.82 \mathrm{~A}$ & $5.60 \mathrm{C}$ & $5.30 \mathrm{E}$ & $5.00 \mathrm{~F}$ & $4.50 \mathrm{H}$ & $4.00 \mathrm{~K}$ & $\mathbf{5 . 0 4} \mathbf{A}$
\end{tabular}




\begin{tabular}{|c|c|c|c|c|c|c|c|}
\hline $\begin{array}{l}\text { Control } \\
\text { Mean }\end{array}$ & $\begin{array}{l}3.97 \mathrm{~K} \\
\mathbf{4 . 9 6} \mathrm{A}\end{array}$ & $\begin{array}{l}3.50 \mathrm{M} \\
\mathbf{4 . 5 6} \mathrm{B}\end{array}$ & $\begin{array}{l}3.00 \mathrm{O} \\
\mathbf{4 . 1 4} \mathbf{C}\end{array}$ & $\begin{array}{l}2.50 \mathrm{R} \\
3.77 \mathrm{D}\end{array}$ & $\begin{array}{l}2.10 \mathrm{~S} \\
\mathbf{3 . 2 4} \mathbf{E}\end{array}$ & $\begin{array}{l}1.80 \mathrm{~T} \\
\mathbf{2 . 8 2} \mathbf{F}\end{array}$ & $2.81 \mathrm{E}$ \\
\hline & & & seas & 2017 & & & \\
\hline $1 \%$ potassium silicate & $4.12 \mathrm{~K}$ & $3.50 \mathrm{~N}$ & $3.10 \mathrm{Q}$ & $2.70 \mathrm{~T}$ & $3.30 \mathrm{P}$ & $2.80 \mathrm{~S}$ & $3.25 \mathrm{D}$ \\
\hline $2 \%$ potassium silicate & $4.73 \mathrm{G}$ & $3.97 \mathrm{~L}$ & $3.60 \mathrm{M}$ & $3.43 \mathrm{~N}$ & $3.06 \mathrm{Q}$ & $2.50 \mathrm{U}$ & $3.55 \mathrm{C}$ \\
\hline $3 \%$ potassium silicate & $5.64 \mathrm{~B}$ & $5.30 \mathrm{C}$ & $5.00 \mathrm{E}$ & $4.70 \mathrm{G}$ & $4.30 \mathrm{I}$ & $4.00 \mathrm{~L}$ & $4.82 \mathrm{~B}$ \\
\hline $4 \%$ potassium silicate & $5.72 \mathrm{~A}$ & $5.50 \mathrm{~B}$ & $5.20 \mathrm{D}$ & $4.90 \mathrm{~F}$ & $4.50 \mathrm{H}$ & $4.20 \mathrm{~J}$ & $5.00 \mathrm{~A}$ \\
\hline Control & $3.41 \mathrm{O}$ & $3.00 \mathrm{R}$ & $2.30 \mathrm{~V}$ & $2.00 \mathrm{~W}$ & $1.38 \mathrm{X}$ & $1.10 \mathrm{Y}$ & $2.20 \mathrm{E}$ \\
\hline Mean & $4.72 \mathrm{~A}$ & $4.25 \mathrm{~B}$ & $3.84 \mathrm{C}$ & $3.55 \mathrm{D}$ & $3.31 \mathrm{E}$ & 2.92 F & \\
\hline
\end{tabular}

Means in the same column having the same letter are not significantly different at 0.05 level by Duncan's multiple rang test.

Ascorbic acid:

Data in Table (13) show that ascorbic acid content of cucumber fruit was significantly decreased by the prolongation of storage period. These results are true in the two seasons and in agreement with those of Shehata et al. (2009).

Concerning the effect of pre-harvest treatments, data reveal that there were significant differences between all concentrations of potassium silicate and untreated control in ascorbic acid content of fruit during storage. However, fruits obtained from plants sprayed with potassium silicate at $4 \%$ were higher in fruit ascorbic acid followed by potassium silicate at $3 \%$ with no significant differences between them, while potassium silicate at $1 \%$ or $2 \%$ were less effective in this concern. The lowest value of ascorbic acid content was obtained from untreated control. These results are in agreement with those of Afifi (2016).

In general, the interaction between pre-harvest treatments and storage period was significant, however, cucumber fruits obtained from plants sprayed with potassium silicate at $4 \%$ were the best in maintaining ascorbic acid content at the end of storage period (15 days) and may be due to potassium silicate might reduce respiration rate of the fruit and inhibited the physiological processes which in turn reduce the loss of ascorbic acid during storage (Jamali and Rahemi, 2011).

Table 13. Effect of foliar spray with potassium silicate on ascorbic acid content (mg/ $100 \mathrm{mg}$ F.W.) of cucumber fruits during storage at $10^{\circ} \mathrm{C}$ in 2016 and 2017 seasons.

\begin{tabular}{|c|c|c|c|c|c|c|c|}
\hline \multirow[t]{2}{*}{ Treatments } & \multicolumn{6}{|c|}{$\begin{array}{l}\text { Storage period in days } \\
\text { season } 2016\end{array}$} & \multirow[t]{2}{*}{ Mean } \\
\hline & Start & 3 & 6 & 9 & 12 & 15 & \\
\hline $1 \%$ potassium silicate & $104.00 \mathrm{DF}$ & 101.30FH & $95.00 \mathrm{IK}$ & 83.0NO & $\begin{array}{l}76.10 \\
\text { PQ } \\
86.00\end{array}$ & $68.00 \mathrm{R}$ & $87.91 \mathrm{C}$ \\
\hline $2 \%$ potassium silicate & 106.30 CF & 104.70DF & $101.30 \mathrm{CH}$ & $93.00 \mathrm{IK}$ & $\begin{array}{l}\mathrm{LN} \\
90.00\end{array}$ & $\begin{array}{l}80.00 \mathrm{OP} \\
85.00\end{array}$ & $\begin{array}{l}95.22 \text { B } \\
100.60\end{array}$ \\
\hline $3 \%$ potassium silicate & $113.30 \mathrm{AB}$ & $110.70 \mathrm{AC}$ & 108.00 BE & $96.40 \mathrm{HJ}$ & KM & $\begin{array}{l}\text { MO } \\
89.40\end{array}$ & $\begin{array}{l}\mathrm{A} \\
102.80\end{array}$ \\
\hline $4 \%$ potassium silicate & $115.10 \mathrm{~A}$ & $111.00 \mathrm{AC}$ & 108.80BD & $98.20 \mathrm{GI}$ & $\begin{array}{l}94.00 \mathrm{IK} \\
70.80\end{array}$ & $\begin{array}{l}\text { KM } \\
70.80\end{array}$ & A \\
\hline $\begin{array}{l}\text { Control } \\
\text { Mean }\end{array}$ & $\begin{array}{l}\text { 100.10EG } \\
\mathbf{1 0 7 . 7 6} \mathbf{A}\end{array}$ & $\begin{array}{l}95.00 \mathrm{GI} \\
\mathbf{1 0 4 . 5 4} \mathbf{B}\end{array}$ & $\begin{array}{l}91.00 \mathrm{JL} \\
\mathbf{1 0 0 . 8 2} \mathbf{C}\end{array}$ & $\begin{array}{l}\text { 71.00QR } \\
\mathbf{8 8 . 3 2} \text { D }\end{array}$ & $\begin{array}{l}\text { QR } \\
\text { 83.38 E }\end{array}$ & $\begin{array}{l}\text { QR } \\
\mathbf{7 6 . 6 8 ~ F}\end{array}$ & 83.12 D \\
\hline \multicolumn{8}{|c|}{ season 2017} \\
\hline $1 \%$ potassium silicate & 101.0 DE & $98.33 \mathrm{EF}$ & $92.00 \mathrm{GH}$ & $80.00 \mathrm{JK}$ & $73.10 \mathrm{~L}$ & $\begin{array}{l}65.00 \mathrm{M} \\
77.00\end{array}$ & $84.91 \mathrm{C}$ \\
\hline $2 \%$ potassium silicate & 104.10AC & 101.70CE & $97.30 \mathrm{CE}$ & $90.00 \mathrm{GH}$ & $83.00 \mathrm{IJ}$ & $\begin{array}{l}\text { KL } \\
82.00 \quad \text { I- }\end{array}$ & $92.43 \mathrm{~B}$ \\
\hline $3 \%$ potassium silicate & $110.30 \mathrm{AB}$ & 107.70AC & 105.00BD & $93.40 \mathrm{FG}$ & $\begin{array}{l}87.00 \mathrm{HI} \\
91.00\end{array}$ & K & $97.57 \mathrm{~A}$ \\
\hline $4 \%$ potassium silicate & $112.10 \mathrm{~A}$ & 108.00AC & 105.80BD & $95.20 \mathrm{FG}$ & $\mathrm{GH}$ & $86.40 \mathrm{HI}$ & $99.75 \mathrm{~A}$ \\
\hline Control & $94.67 \mathrm{EF}$ & $90.00 \mathrm{FG}$ & $84.00 \mathrm{HI}$ & $67.00 \mathrm{M}$ & $66.80 \mathrm{M}$ & $57.00 \mathrm{~N}$ & $76.82 \mathrm{D}$ \\
\hline Mean & $104.43 \mathrm{~A}$ & 101.15 B & $96.82 \mathrm{C}$ & 85.12 D & 80.18 E & 73.48 F & \\
\hline
\end{tabular}

Means in the same column having the same letter are not significantly different at 0.05 level by Duncan's multiple rang test.

Total soluble solids (TSS) percentage:

Data in Table (14) indicate that TSS \% of cucumber fruits decreased with the prolongation of storage period. These results are in agreement with those obtained by Shehata et al.(2009) on cucumber fruits. The hydrolysis of fruit starch is completed, no further increase in TSS\% could be detected and subsequently, a decline in this parameter predictable 
since sugars along with other organic acids is primary substrates used for respiration (Gerasopouls and Drogoudi, 2005).Concerning the effect of preharvest treatments, data reveal that there were significant differences between all concentrations of potassium silicate treatments and untreated control on TSS\% of fruits during storage. Cucumber fruits obtained from plants sprayed with potassium silicate at $3 \%$ or $4 \%$ were the most effective treatments in maintaining TSS\% with no significant differences between them, while the lowest ones in this concern were recorded for fruits obtained from untreated plants. These results are in agreement with those of Lalithya et al.(2014) and may be due to that potassium silicate helped in synthesis of more sugar content in fruit and thus resulted in increasing maximum TSS\%, Also, Tarahih et al. (2014) found that potassium silicate reduced respiration rate, ethylene production, therefore reduces the physiological processes.

In general, the interaction between pre-harvest treatments and storage period was significant. After 15 days of storage, data show that cucumber fruits obtained from plants sprayed with potassium silicate at $4 \%$ gave the highest values of TSS followed by potassium silicate at $3 \%$ with significant differences between them, while the lowest ones were found in those obtained from untreated plants.

Table 14. Effect of foliar spray with potassium silicate on TSS $\%$ of cucumber fruits during storage at $10^{\circ} \mathrm{C}$ in 2016 and 2017 seasons.

\begin{tabular}{|c|c|c|c|c|c|c|c|}
\hline \multirow[t]{2}{*}{ Treatments } & \multicolumn{6}{|c|}{ Storage period in days } & \multirow[t]{2}{*}{ Mean } \\
\hline & Start & 3 & 6 & 9 & 12 & 15 & \\
\hline $1 \%$ potassium silicate & $3.40 \mathrm{AF}$ & $3.10 \mathrm{DI}$ & $2.90 \mathrm{FJ}$ & $2.60 \mathrm{IL}$ & $2.30 \mathrm{KM}$ & $2.10 \mathrm{LM}$ & $2.73 \mathrm{C}$ \\
\hline $2 \%$ potassium silicate & $3.70 \mathrm{AC}$ & $3.50 \mathrm{AE}$ & $3.80 \mathrm{AB}$ & $3.00 \mathrm{EI}$ & $2.70 \mathrm{HK}$ & $2.40 \mathrm{JL}$ & $3.18 \mathrm{~B}$ \\
\hline 3\% potassium silicate & $3.90 \mathrm{~A}$ & $3.70 \mathrm{AC}$ & $3.58 \mathrm{AD}$ & $3.20 \mathrm{CH}$ & $3.10 \mathrm{DI}$ & $2.80 \mathrm{GK}$ & 3.38AB \\
\hline $4 \%$ potassium silicate & $3.81 \mathrm{AB}$ & $3.75 \mathrm{AB}$ & $3.64 \mathrm{AD}$ & $3.27 \mathrm{BG}$ & $3.13 \mathrm{DI}$ & $3.00 \mathrm{EI}$ & $3.43 \mathrm{~A}$ \\
\hline Control & $3.13 \mathrm{DI}$ & $2.90 \mathrm{FJ}$ & $2.60 \mathrm{IL}$ & $2.30 \mathrm{KM}$ & 2.10 LM & $1.80 \mathrm{M}$ & 2.47 D \\
\hline Mean & $3.59 \mathrm{~A}$ & 3.39 AB & $3.30 \mathrm{~B}$ & $2.87 \mathrm{C}$ & $2.67 \mathrm{C}$ & $2.42 \mathrm{D}$ & \\
\hline \multicolumn{8}{|c|}{ season 2017} \\
\hline $1 \%$ potassium silicate & $2.80 \mathrm{CG}$ & $2.50 \mathrm{FI}$ & $2.30 \mathrm{GJ}$ & $2.00 \mathrm{IL}$ & $1.70 \mathrm{KM}$ & $1.50 \mathrm{LM}$ & $2.13 \mathrm{C}$ \\
\hline $2 \%$ potassium silicate & $3.10 \mathrm{AE}$ & $2.90 \mathrm{BF}$ & $3.20 \mathrm{AD}$ & $2.40 \mathrm{FI}$ & $2.10 \mathrm{HK}$ & $1.80 \mathrm{JL}$ & $2.58 \mathrm{~B}$ \\
\hline $3 \%$ potassium silicate & $3.50 \mathrm{~A}$ & $3.30 \mathrm{AC}$ & $3.18 \mathrm{AD}$ & $2.80 \mathrm{CG}$ & $2.70 \mathrm{DG}$ & $2.40 \mathrm{FI}$ & $2.98 \mathrm{~A}$ \\
\hline $4 \%$ potassium silicate & $3.41 \mathrm{AB}$ & $3.35 \mathrm{AB}$ & $3.24 \mathrm{AD}$ & $2.87 \mathrm{BF}$ & $2.73 \mathrm{DG}$ & $2.60 \mathrm{EH}$ & $3.03 \mathrm{~A}$ \\
\hline Control & $2.53 \mathrm{FI}$ & $2.30 \mathrm{GJ}$ & $2.00 \mathrm{IL}$ & $1.70 \mathrm{KM}$ & $1.50 \mathrm{LM}$ & $1.20 \mathrm{M}$ & 1.87 D \\
\hline Mean & $3.07 \mathrm{~A}$ & $2.87 \mathrm{AB}$ & $2.78 \mathrm{~B}$ & $2.35 \mathrm{C}$ & $2.15 \mathrm{C}$ & $1.90 \mathrm{D}$ & \\
\hline
\end{tabular}

Means in the same column having the same letter are not significantly different at 0.05 level by Duncan's multiple rang test.

\section{References}

A.O.A.C. 2000. Association of Official Analytical Chemists. Washington DC. International $17^{\text {th }}$ Edition, Revision I pp. 490-510.

Afifi, E.H.E. 2016. Effect of Some pre and postharvest Treatments on Storability of Strawberry Fruits. M.Sc. Thesis, Faculty of Agriculture, Ain Shams University, Egypt 149 pp.

Agarie, S.; N. Hanaoka; O. Ueno; A. Miyazaki; F. Kubota; W. Agata and P.B. Kaufman. 1998. Effects of silicon on tolerance to water deficit and heat stress in rice plants (Oryza sativa L.), monitored by electrolyte leakage. Prod. Sci., 1: 96-103.

Al-Aghabary, K.; Z.J. Zhu and Q.H. Shi. 2004. Influence of silicon supply on chlorophyll content, chlorophyll fluorescence and antioxidative enzyme activities in tomato plants under salt stress. J. Plant Nutr., 27: 2101-2115.

Dong, H.; Y. Jiang; Y.Wang; R. Lu and H. Guan. 2004. Effects of hot water immersion on storage quality of fresh broccoli heads. Food Technol. Biotechnol., 42 (2): 135-139.
Emadian, S.F. and R.J. Newton. 1989. Growth enhancement of loblolly pine (Pinus taeda L.) seedling by silicon. J. Plant Physiol., 134:98-103.

Epstein, E. 1999. Silicon. Annu. Res. Plant Physiol. Plant Mol. Biol., 50: 641-664.

Epstein, E. 2001. Silicon in plants: Facts vs. concepts. In L.E. Datnoff, G.H. Snyder, and G.H. Korndörfer (ed.) Elsevier, N. Y., 1-15.

Epstien, E.; J.D. Norlyn and C. Cabot. 1988. Silicon and plant growth. Plant Physiol., 86(4):804 p.

Gerasopouls, D. and P.D. Drogoudi. 2005. Summer-pruning and preharvest calcium chloride sprays affect storability and low temperature breakdown incidence in kiwifruit. Post-Harvest Biol. Techno., 56:303-308.

Gorecki, R.S. and W. Danieski-Busch. 2009. Effect of silicate fertilizers on yielding of greenhouse cucumber (Cucumis sativus L.) in container cultivation. J. Elemental., 14(1): 71-78.

Hammash, F. and N. El Assi. 2007. The influence of pre storage waxing and wrapping on quality attributes of stored 'Shamouti' orange. Acta Hortic., 740:133-140. 
Hiorse, T. 1985. Effect of pre and interposed warming on chilling injury, respiratory and membrane permability of cucumber fruits during cold storage. J. JPN. Soc. Hotic. Sci., 53:459-466.

Ibrahim, H.I. and M.M. Al-Wasfy. 2014. The promotive impact of using silicon and selenium with potassium and boron on fruiting of Valencia orange trees grown under Minia region condition. W. Rur. Obs., 6(2): 28-36.

Jamali, B. and M. Rahemi. 2011. Carnation flowers senescence as influenced by nickel, cobalt and silicon. J. Biol. Environ. Sci., 5(15): 147-152.

Jarosz, Z. 2013. The effect of silicon application and type of substrate on yield and composition of leaves of cucumber. J. Elem., 18(3):403-414.

Kaluwa, K.; I. Bertling; J.P. Bower and S.Z. Tesfay. 2010. Silicon application effects on 'Hass' avocado fruit physiology. South African Avocado Growers Association, Year Book, 33 pp.

Kanto, T.; A. Miyoshi; T. Ogawa; K. Maekawa and M. Aino. 2004. Suppressive effect of potassium silicate on powdery mildew of strawberry in hydroponic. J. Gen. Plant Pathol., 70:207-211.

Lalithya, K.A.; H.P. Bhagya; K. Bharathi and R. Choudhary. 2014. Response of silicon and micro nutrients on fruit character and nutrient content in leaf of sapota. Biolife, 2(2):593-598.

Liang, Y.C.; X.H. Chen; T.S. MA; Z.J. Qian and L.R. Liu. 1993. Effect of $\mathrm{Si}$ on the growth, yield and quality of tomato. Jiangsu Agric. Sci., 4:4850.

Ma, J.F. 2004. Role of silicon in enhancing the resistance of plants to biotic and abiotic stresses. Soil Sci. Plant Nutr., 50 (1): 11-18.

Marodin, J.C.; J.T. Resende; R.G. Morales; M.L. Silva; A.G. Galvão and D.S. Zanin. 2014. Yield of tomato fruits in relation to silicon sources and rates. Hortic. Bras., 32:220-224.

McGuire, R.G. 1992. Reporting of objective color measurements. HortScience, 27: 1254-1255.

Miyake, Y. and E. Takahashi. 1983. Effect of silicon on the growth of cucumber plant in soil culture. Soil Sci. Plant Nutr., 29: 463-471.

Nesreen, H. Abou-Baker; M. Abd-Eladl and M. A. Mohsen. 2011. Use of silicate and different cultivation practices in alleviating salt stress effect on bean plants. Australian J. Basic \& Applied Sci., 5(9): 769-781.

Rageh, M.A. and S.M. Abou-Elwafa. 2017. Effect of jasmin oil and active dry yeast as a preharvest spray on alleviating chilling injury in cucumber fruits during cold storage. Middel East J. Agric. Res., 6(4): 1144-1154.
Samuels, A.L.; A.D. Glass; D.L. Ehret and J.G. Menzies. 1993. The effects of silicon supplementation on cucumber fruit: changes in surface characteristics. Ann. Bot., 72: 433-440.

Shehata, S.A.; M.Y. Hashem and M.M. Attia. 2009. Combined application of hot water and low temperature conditioning reduced chilling injury and maintained quality of cucumber fruits during storage. Annals of Agric. Sci., Moshtohor, 49(3): 27-34.

Shetty, R.; B. Jensen; N. P. Shetty; M. Hansen; C. W. Hansen; K. R. Starkey and H. J. L. Jørgensen. 2012. Silicon induced resistance against powdery mildew of roses caused by Podosphaera pannosa. Plant Pathol., 61: 120131.

Snedecor, G.W. and W.G. Cochran. 1980. Statistical Methods. $8^{\text {th }}$ Ed., Iowa State Univ. Press, Ames, Iowa, USA., 476 pp.

Stefánsson, A.; I. Gunnarsson and N. Giroud. 2007. New methods for the direct determination of dissolved inorganic, organic and total carbon in natural waters by Reagent-Free Ion Chromatography and inductively coupled plasma atomic emission spectrometry. Anal. Chim. Acta, 582 (1): 69-74.

Tarabih, M.E.; E.E. EL-Eryan and M.A. ELMetwally. 2014. Physiological and pathological impacts of potassium silicate on storability of Anna apple fruits. Am. J. Plant Physiol., 9: 5267.

Tesfay, S.Z.; I. Bertling and J.P. Bower. 2011. Effects of postharvest potassium silicate application on phenolics and other anti-oxidant systems aligned to avocado fruit quality. Postharvest Biol. Technol., 60: 92-99.

Voogt, W. and C. Sonneveld. 2001. Silicon in horticultural crops grown in soilless culture, p.115-129. In: Datnoff, L.E., G.H. Snyder, and G.H. Kornd"orfer (eds.). Silicon in Agriculture. Elsevier Science B.V., Amsterdam, the Netherlands.

Wang, C.Y. and L. Qi. 1997. Modified atmosphere package alleviates chilling injury in cucumbers. Postharvest Biol. and Technol., 10:195-200.

Wills, R.; B. Mcglasson; D. Graham and D. Joyce. 1998. Postharvest: An introduction to the physiology and handling of fruit, vegetables and ornamentals. Ed.: CAB International, Wallingford, UK. Zagazig J. Agric. Res., 17:877882.

Wolff, S.A.; J. Rohloff and I. Karoliussen. 2008. Inhibitory effects of foliar applied $\mathrm{Si}$ on powdery mildew in greenhouse cucumber. Silicon in Agriculture $4^{\text {th }}$ International Conference Port Edward, South Africa, 106 p. 


\section{تأثير الرش الورقى بسليكات البوتاسيوم على النمو الخضرى والمحصول والجودة والقدرة التخزينية لثمار الخيار.}



$$
\text { 1 . مسم البساتين - كلية الزراعة - جامعة القاهرة . }
$$

$$
\text { 2. قسم بحوث تداول الخضر - معهد بحوث البساتين - مركز البحوث الزراعية بالجيزة. }
$$

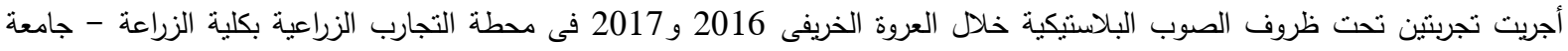

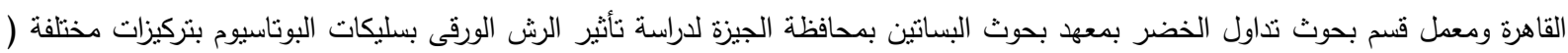
1\% , و 2\% , و 3\% , و4\% ) بالمقارنة بالكنترول (الرش بالماء المقطر) على النمو الخضرى والمحصول ومكوناته والجودة والقدرة التخزينية

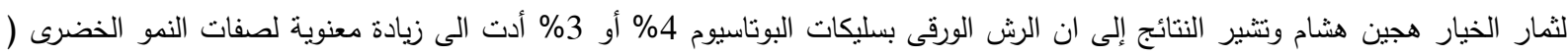



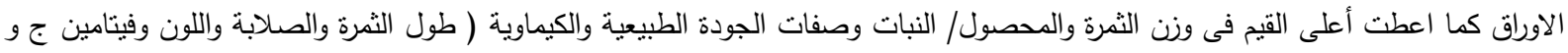
نسبة المواد الصلبة الذائبة الكلية) كما اعطت اعلى محتوى من السليكون والبوتاسيوم فى الثمار مقارنة بباقى المعاملات او النباتات الغير معاملة

أدت المعاملة بسليكات البوتاسيوم 4\% الى تحسين القدرة التخزينية لثمار الخيار حيث أعطت أقل فقد وزن وفقد فى اللون مع المحافظة على جودة

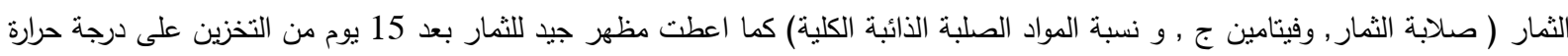

